Prepared in cooperation with the Bureau of Reclamation

\title{
Sediment Transport Monitoring of the Yankee Fork of the Salmon River near Stanley, Idaho, 2012-15
}

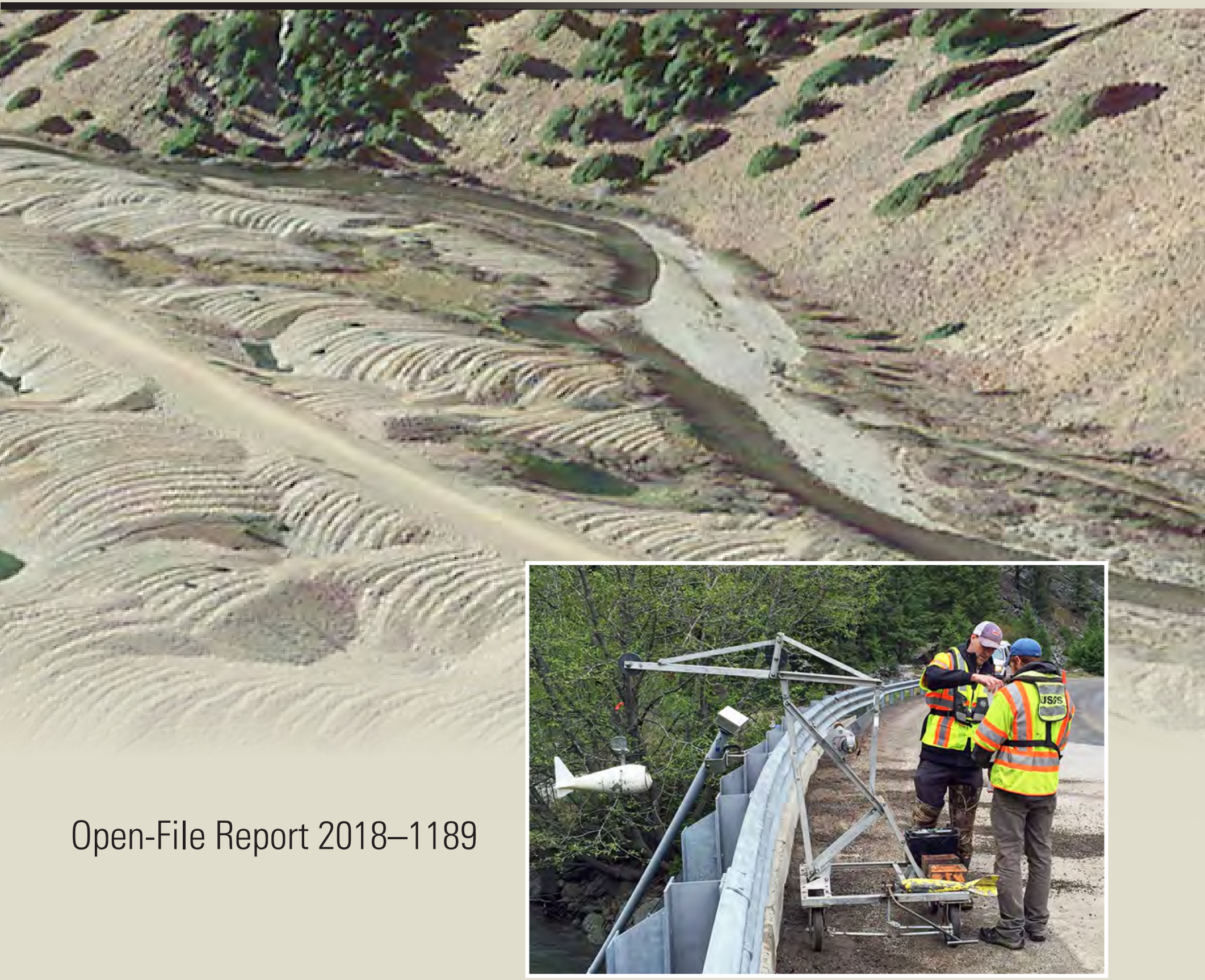

U.S. Department of the Interior

U.S. Geological Survey 
Cover: Aerial image of dredge tailing piles at Yankee Fork of Salmon River, Idaho. Image (C) 2014 Google Earth. Inset photograph: U.S. Geological Survey hydrologic technicians sampling suspended-sediment at the streamgage site of Yankee Fork of the Salmon River near Stanley, Idaho. Photograph by Doug Ott, U.S. Geological Survey, May 23, 2016. 


\section{Sediment Transport Monitoring of the Yankee Fork of the Salmon River near Stanley, Idaho, 2012-15}

By James W. Johnsen

Prepared in cooperation with the Bureau of Reclamation

Open-File Report 2018-1189 


\section{U.S. Department of the Interior \\ RYAN K. ZINKE, Secretary}

\section{U.S. Geological Survey \\ James F. Reilly II, Director}

U.S. Geological Survey, Reston, Virginia: 2018

For more information on the USGS-the Federal source for science about the Earth, its natural and living resources, natural hazards, and the environment-visit http://www.usgs.gov/ or call 1-888-ASK-USGS (1-888-275-8747).

For an overview of USGS information products, including maps, imagery, and publications, visit http://www.usgs.gov/pubprod/.

Any use of trade, firm, or product names is for descriptive purposes only and does not imply endorsement by the U.S. Government.

Although this information product, for the most part, is in the public domain, it also may contain copyrighted materials as noted in the text. Permission to reproduce copyrighted items must be secured from the copyright owner.

Suggested citation:

Johnsen, J.W., 2018, Sediment transport monitoring of the Yankee Fork of the Salmon River near Stanley, Idaho, 2012-15: U.S. Geological Survey Open-File Report 2018-1189, 17 p., https://doi.org/10.3133/ofr20181189.

ISSN 2331-1258 (online) 


\section{Contents}

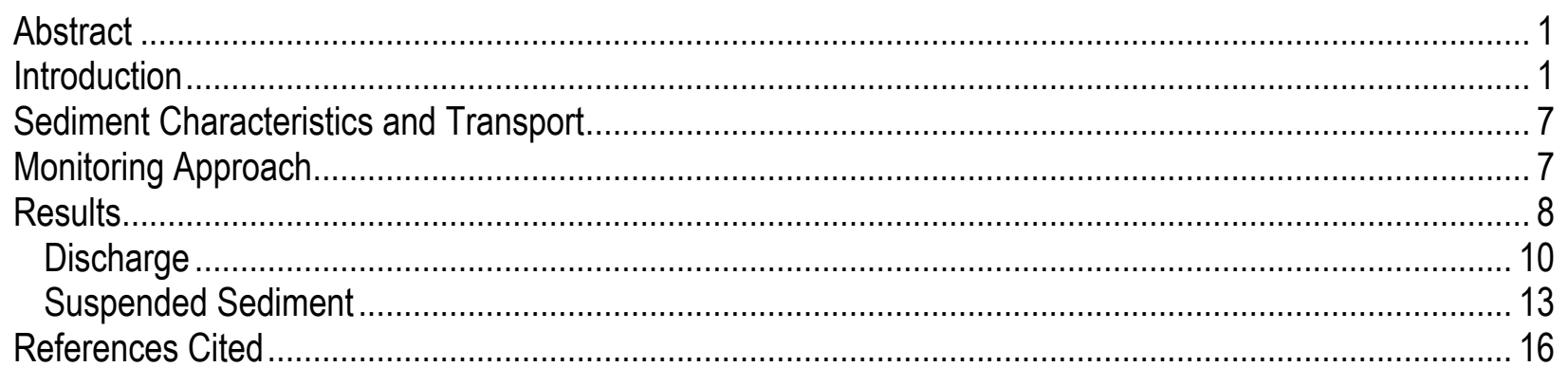

\section{Figures}

Figure 1. Map showing Yankee Fork of the Salmon River near Stanley, Idaho ...................................... 2

Figure 2. Photographs showing dredging and tailings of the Yankee Fork of the Salmon River near

Stanley, Idaho ..................................................................................................................... 3

Figure 3. Photograph showing engineered log jams on the Yankee Fork of the Salmon River near Stanley, Idaho.

Figure 4. Photograph showing U.S. Geological Survey hydrologist sampling suspended sediment at the Gage site on the Yankee Fork of the Salmon River near Stanley, Idaho. Photograph by Doug Ott, U.S. Geological Survey, May 23, 2016 ...

Figure 5. Map showing sampling and measurement locations, Yankee Fork of the Salmon River near Stanley, Idaho.

Figure 6. Graph showing stream discharge measurements of the Bonanza and Confluence sites plotted against the Gage site measurements (U.S. Geological Survey streamgage 13296000), Yankee Fork of the Salmon River near Stanley, Idaho.

Figure 7. Graphs showing suspended-sediment concentrations plotted against stream discharge measurements for (A) Bonanza, (B) Confluence, and (C) Gage sites, Yankee Fork of the Salmon River near Stanley, Idaho...

Figure 8. Graphs showing percentage of suspended-sediment sand-size and larger (percentage by weight greater than $0.0625 \mathrm{~mm}$ ) for $(A)$ Bonanza, $(B)$ Confluence, and $(C)$ Gage sites, Yankee Fork of the Salmon River near Stanley, Idaho

\section{Tables}

Table 1. Sampling and measurement locations, Yankee Fork of the Salmon River near Stanley, Idaho ......7 Table 2. Stream discharge and suspended-sediment results, Yankee Fork of the Salmon River near Stanley, Idaho.

Table 3. Pseudo-hydrograph regression statistics for the Bonanza and Confluence sites, Yankee Fork of the Salmon River near Stanley, Idaho 


\section{Conversion Factors}

U.S. customary units to International System of Units

$$
\text { Multiply }
$$

cubic foot per second $\left(\mathrm{ft}^{3} / \mathrm{s}\right)$

$$
\text { By }
$$

Flow rate 0.02832

To obtain

cubic foot per second $\left(\mathrm{ft}^{3} / \mathrm{s}\right)$

International System of Units to U.S. customary units

\begin{tabular}{lccc}
\hline & Multiply & By & To obtain \\
\hline & Length & & \\
\hline millimeter $(\mathrm{mm})$ & 0.03937 & inch (in.) & \\
\hline
\end{tabular}

\section{Datums}

Vertical coordinate information is referenced to the National Geodetic Vertical Datum of 1929 (NGVD 29)

Horizontal coordinate information is referenced to the North American Datum of 1983 (NAD 83). Altitude, as used in this report, refers to distance above the vertical datum.

\section{Supplemental Information}

Concentrations of chemical constituents in water are given in either milligrams per liter $(\mathrm{mg} / \mathrm{L})$ or micrograms per liter $(\mu \mathrm{g} / \mathrm{L})$. 


\title{
Sediment Transport Monitoring of the Yankee Fork of the Salmon River near Stanley, Idaho, 2012-15
}

By James Johnsen

\begin{abstract}
The Yankee Fork of the Salmon River is one of the larger watersheds in the upper Salmon River subbasin of central Idaho. Mining activities since the late 19th century, specifically placer mining and associated dredging from 1940 to 1953, have left the fluvial system in a highly altered and unnatural state. To improve aquatic and terrestrial habitat in the Yankee Fork, the Bureau of Reclamation and other stakeholders collaborated on the Dredge Tailings Restoration Project and Yankee Fork Rehabilitation Project. In conjunction with these rehabilitation efforts, the U.S. Geological Survey monitored suspended-sediment transport and discharge between 2012 and 2015 at three sites in the lower reaches of the Yankee Fork. Pseudo-hydrographs were developed for the Bonanza and Confluence sites using data from the streamgage site as a surrogate. Results showed a good fit between measured and calculated discharge with $\mathrm{R}^{2}$ values of 0.96 for the Bonanza site and 0.98 for the Confluence site. Both regressions have high hypothesis test statistics $(t>23)$ and low probability values $(\mathrm{p}<0.0001)$, indicating a strong linear correlation. Suspended-sediment samples collected mostly during snowmelt runoff showed a positive correlation with stream discharge. Hysteresis in the sample results indicates a supply-limited suspended-sediment transport regime. Percent sand by weight of suspended-sediment samples identified a possible discharge threshold for sand suspension at about 400 cubic feet per second $\left(\mathrm{ft}^{3} / \mathrm{s}\right)$ at the Bonanza site and about 1,000 $\mathrm{ft}^{3} / \mathrm{s}^{\text {at }}$ the Confluence and Gage sites.
\end{abstract}

\section{Introduction}

The Yankee Fork of the Salmon River (Yankee Fork) is one of the larger watersheds in the upper Salmon River subbasin of central Idaho (National Oceanic and Atmospheric Administration, 2010; fig. 1). Various mining activities occurred in the Yankee Fork beginning in the late 19th century (Rhea and others, 2013; Wolford, 1999). More recently (1940-1953), placer mining and associated dredging from the Jordan to Polecamp Creek confluences left the fluvial system in a highly altered and unnatural state (Bureau of Reclamation 2012a, 2013; figs. $2 A$ and 2B). Habitat quantity and quality suffered in these unnatural conditions, resulting in disconnected off-channel habitats, confined stream channels, disconnected historic floodplains, and lack of vegetation (Bureau of Reclamation, 2012b, 2012c). 


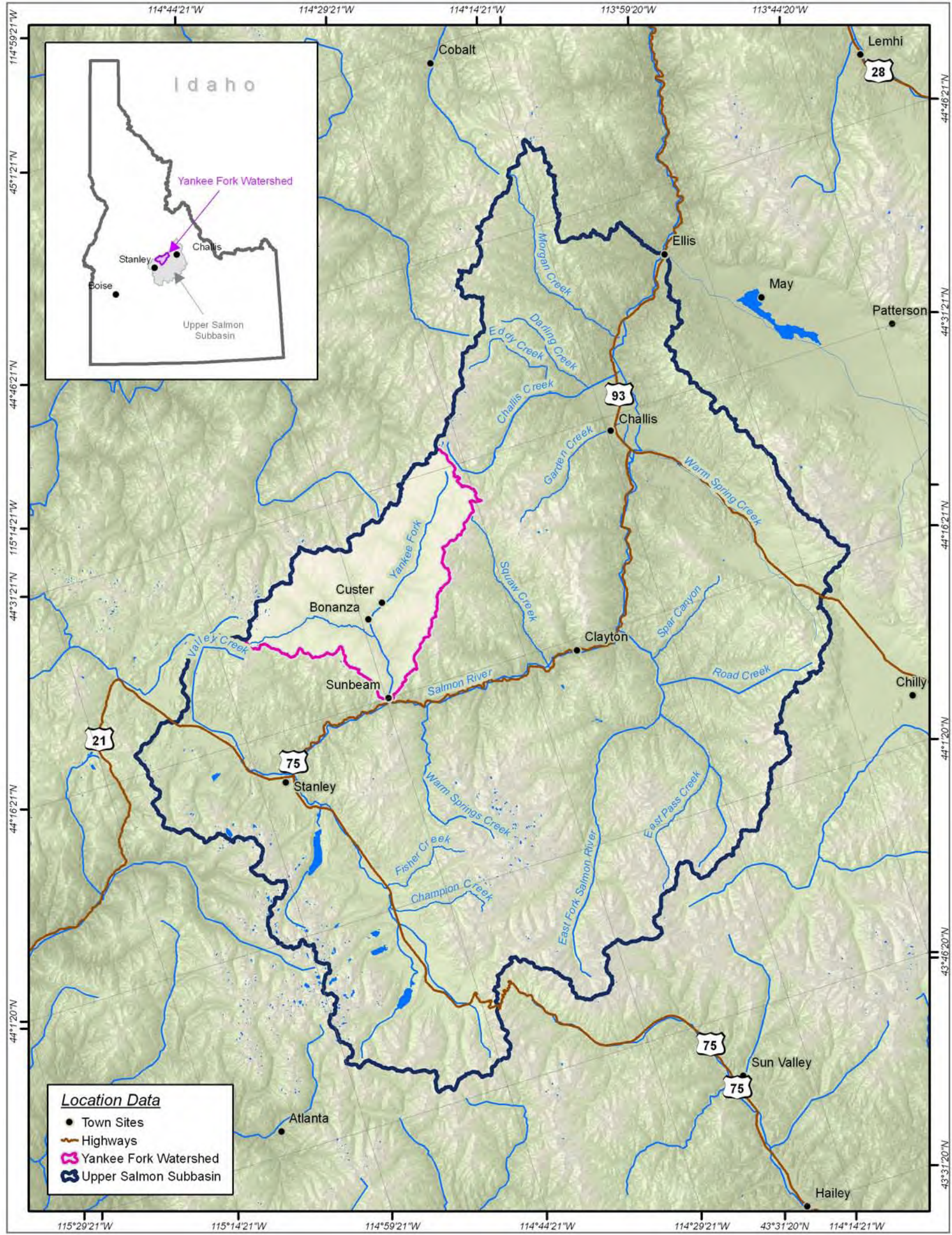

Figure 1. Map showing Yankee Fork of the Salmon River near Stanley, Idaho. 


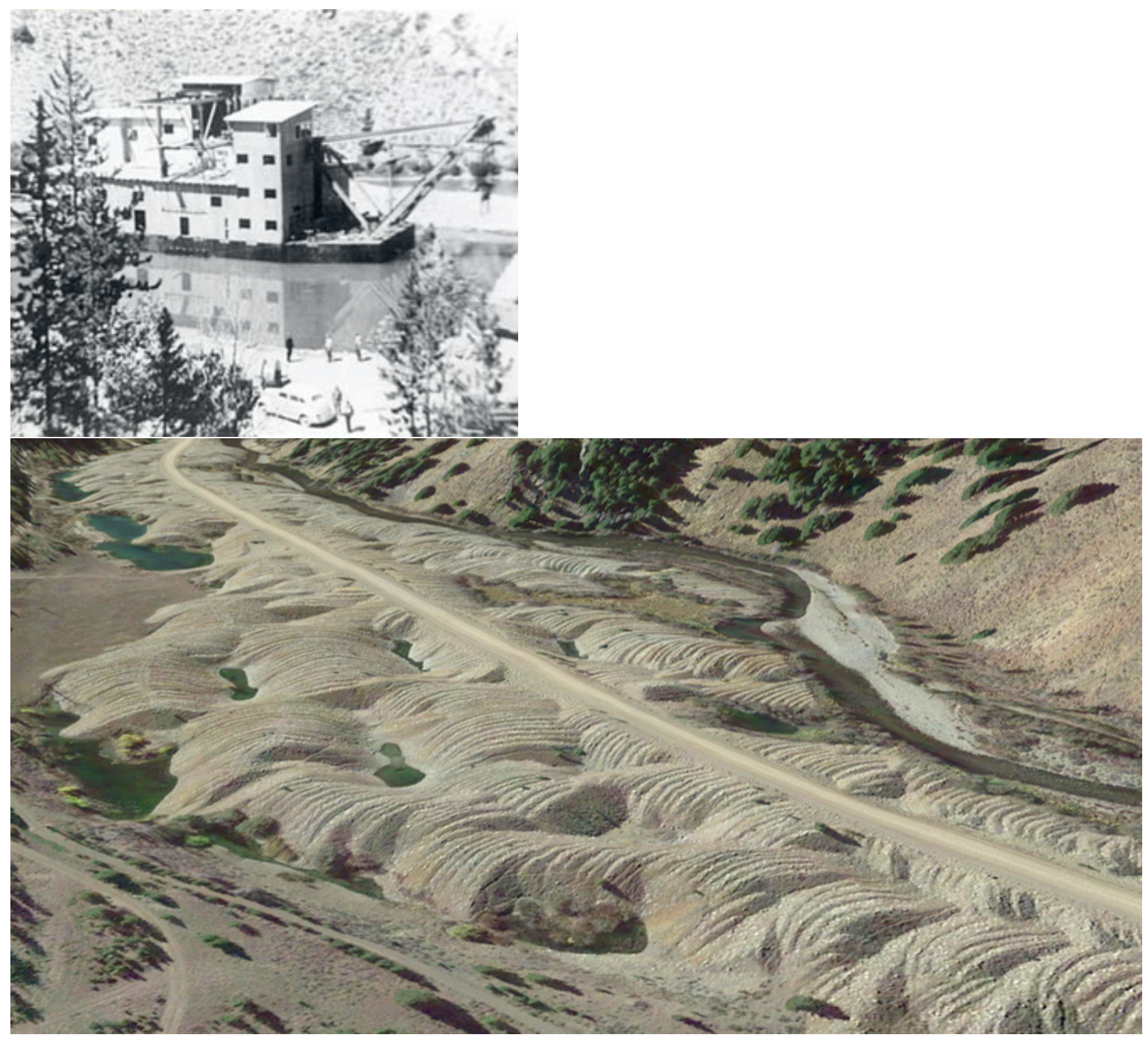

Figure 2. Photographs showing dredging and tailings of the Yankee Fork of the Salmon River near Stanley, Idaho. Photograph A, historical photograph of the Yankee Fork Dredge, photographer unknown, date unknown; Photograph B, Yankee Fork dredge tailings, source Google Earth®, October 6, 2014. 
To improve aquatic and terrestrial habitat in the Yankee Fork, the Bureau of Reclamation and other stakeholders collaborated on the Dredge Tailings Restoration Project and Yankee Fork Rehabilitation Project (fig. 3). The objective of these restoration efforts was to reconnect historical channel and floodplain interactions, re-establish connectivity with tributaries, and enhance floodplane, tributary, and instream complexity. Another action of these projects was to monitor and maintain high quality functioning habitats and water quality; and, modify past rehabilitation actions to improve and diversify habitats through adaptive management. The monitoring and adaptive management aspects of the restoration projects would provide baseline data of pre-rehabilitation conditions (Kondolf, 1995; Kondolf and Micheli, 1995). These data were then to be used to help with channel design by providing the thresholds for substrate mobility, and to adapt rehabilitation actions to maximize efforts (Wood and Armitage, 1997). Furthermore, monitoring data were to be compared to post-rehabilitation conditions to quantify the degree to which objectives were met (Federal Interagency Stream Restoration Working Group, 1998).

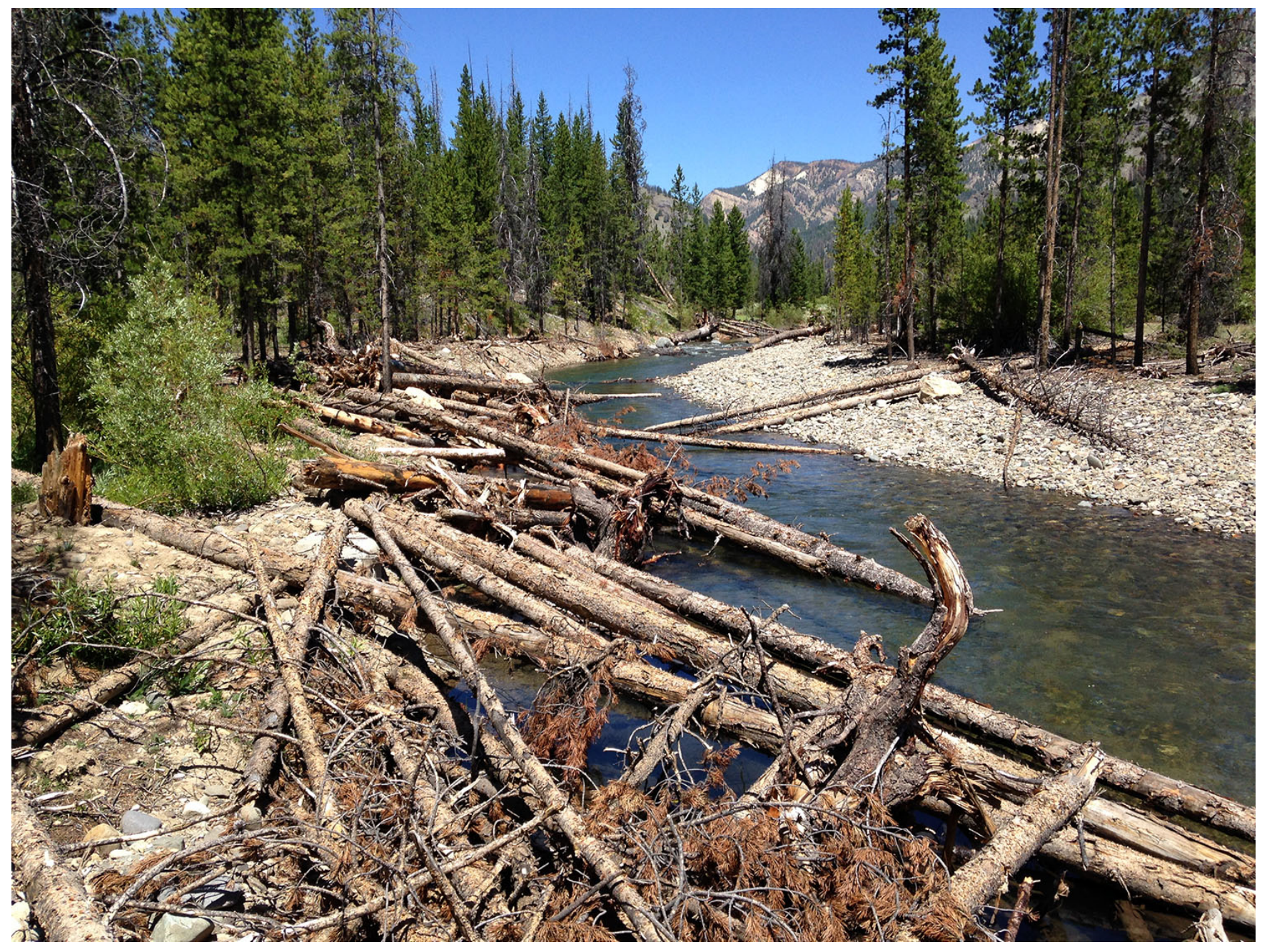

Figure 3. Photograph showing engineered log jams on the Yankee Fork of the Salmon River near Stanley, Idaho. Photograph by Bureau of Reclamation, date unknown. 
In conjunction with these rehabilitation efforts, the U.S. Geological Survey (USGS) monitored suspended-sediment transport and stream discharge between 2012 and 2015 at three sites in the lower reaches of the Yankee Fork: USGS 13295850, Yankee Fork Salmon River at Bonanza Bridge, Idaho; USGS 13295900, Yankee Fork Salmon River below WF near Bonanza, ID; and USGS 13296000, Yankee Fork Salmon River near Clayton, Idaho herein referred to as the Bonanza, Confluence and Gage sites, respectively (figs. 4 and 5). Results from these monitoring efforts provided thresholds for channel mobility and hydrographs for un-gaged sites to help with rehabilitation design, provided sediment transport updates for adaptive management purposes, and will be used to compare pre- and post-rehabilitation sediment transport in a final report to evaluate rehabilitation success.

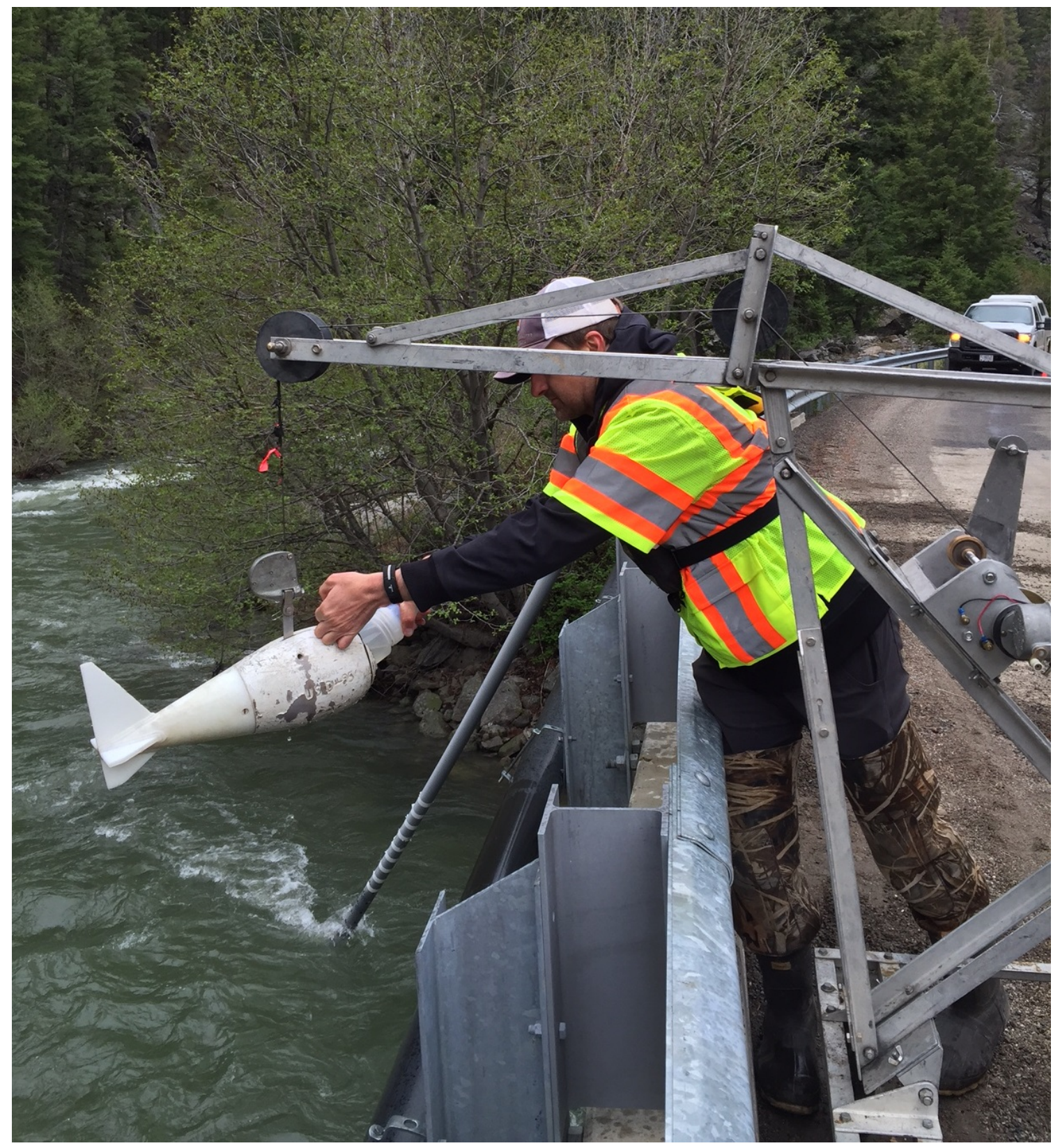

Figure 4. Photograph showing U.S. Geological Survey hydrologist sampling suspended sediment at the Gage site on the Yankee Fork of the Salmon River near Stanley, Idaho. Photograph by Doug Ott, U.S. Geological Survey, May 23, 2016. 


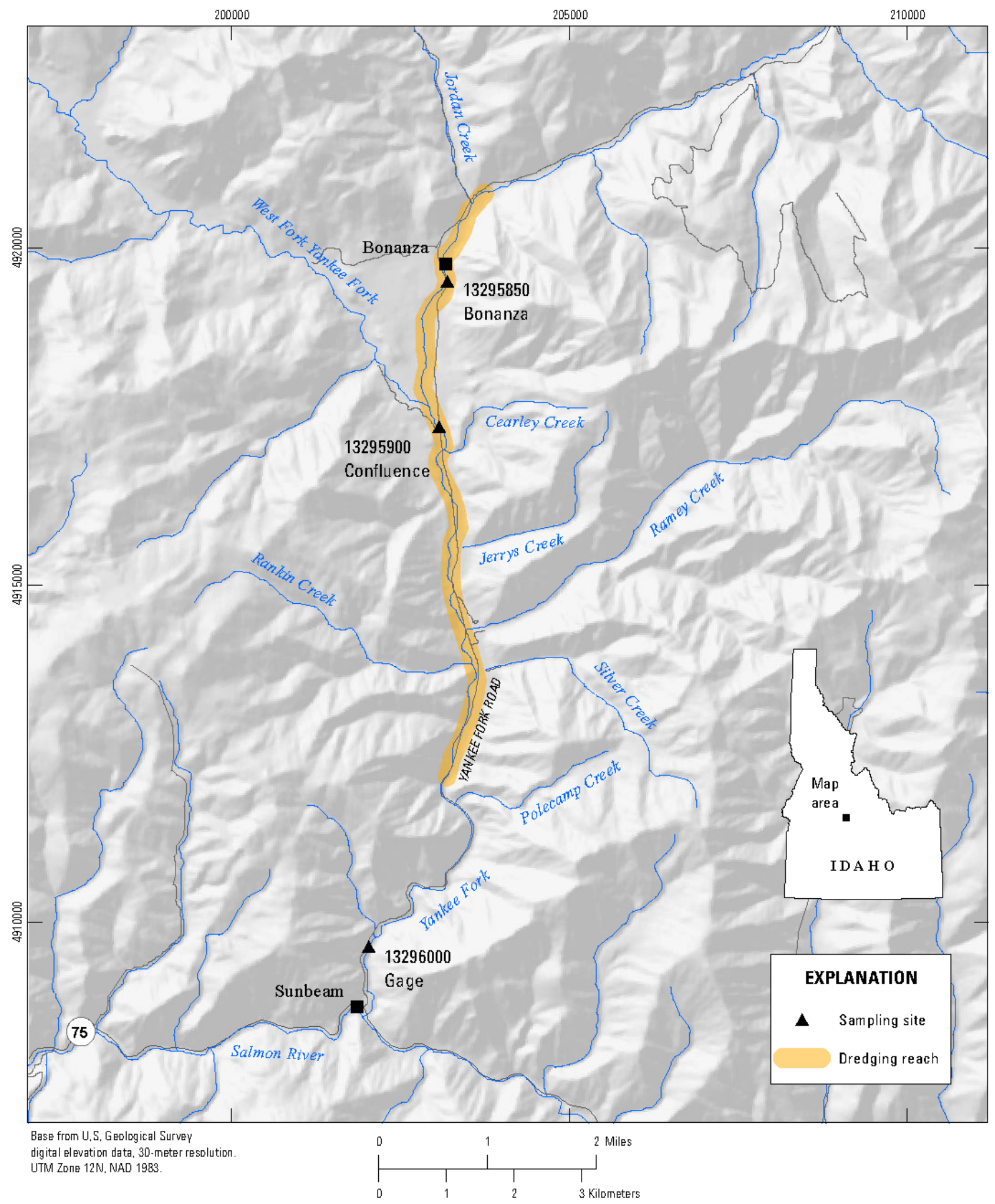

Figure 5. Map showing sampling and measurement locations, Yankee Fork of the Salmon River near Stanley, Idaho. 


\section{Sediment Characteristics and Transport}

Streams transport sediment by maintaining the sand and small sized (fine) particles in suspension (suspended-sediment transport) and by sliding, rolling, or bouncing sand-gravel and large sized (coarse) particles along the streambed (bedload sediment transport; Edwards and Glysson, 1999). The discharge of suspended-sediment is usually dependent on the available supply of such particles; often with the supply being less than what the stream can transport (Colby, 1956). These fine-grained sediments generally move downstream at about the same velocity as the water. When the supply is the limiting factor in sediment discharge, it is a supply limited transport regime. In contrast, the supply of coarse-grained bedload sediments in streams is generally greater than the stream can transport, resulting in bedload moving only occasionally and remaining at rest much of the time. However, at high flows, the coarse sediments can become mobile. When the force of the stream acting on the bed sediments is the limiting factor in the discharge of the sediment in transport, it is a transport-limited regime. Thus, the discharge of bedload sediment is usually dependent on the driving force of the stream (Guy, 1970).

The variability in these sediment-transport mechanisms can result in heterogeneous or homogeneous sediment characteristics of the stream, depending on the sediment supply (availability and characteristics) and stream discharge. When discharge is described as the driving force in sediment mobility, we are relating the discharge to the shear forces acting on the channel material. More specifically, shear stress is a function of depth and slope, which affects the velocity of the water. Therefore, in the case of a large stream rehabilitation where the channel dimensions and slope of the channel are being altered, the same discharge before or after the rehabilitation can be more, or less, competent to mobilize channel sediments.

\section{Monitoring Approach}

The USGS sampled suspended-sediment and stream discharge at three sites Bonanza, Confluence, and Gage (table 1, fig. 5). The Gage site is a full-time USGS streamgage (13296000) that provides real-time, 15-minute stage and temperature data. Discharge is derived from the stagedischarge rating curve in 15-minute intervals (For more information, see USGS website: https://waterdata.usgs.gov/id/nwis/uv/?site_no=13296000).

Table 1. Sampling and measurement locations, Yankee Fork of the Salmon River near Stanley, Idaho.

[Abbreviation: NAD83, North America Datum of 1983; USGS, U.S. Geological Survey]

\begin{tabular}{|c|c|c|c|c|c|c|}
\hline $\begin{array}{l}\text { Sampling } \\
\text { period }\end{array}$ & $\begin{array}{l}\text { USGS site } \\
\text { No. }\end{array}$ & USGS site name & $\begin{array}{l}\text { Reference } \\
\text { site name }\end{array}$ & Latitude & Longitude & Datum \\
\hline $2012-15$ & 13295850 & $\begin{array}{l}\text { Yankee Fork Salmon River at } \\
\text { Bonanza Bridge, ID } \\
\text { (Bonanza) }\end{array}$ & Bonanza & $44^{\circ} 22^{\prime} 04.67^{\prime \prime}$ & $114^{\circ} 43^{\prime} 30.29^{\prime \prime}$ & NAD83 \\
\hline $2012-15$ & 13295900 & $\begin{array}{l}\text { Yankee Fork Salmon River } \\
\text { below WF near Bonanza, ID } \\
\text { (Confluence) }\end{array}$ & Confluence & $44^{\circ} 20^{\prime} 54.63^{\prime \prime}$ & $114^{\circ} 43^{\prime} 30.87^{\prime \prime}$ & NAD83 \\
\hline $2012-15$ & 13296000 & $\begin{array}{l}\text { Yankee Fork Salmon River near } \\
\text { Clayton, ID (Gage) }\end{array}$ & Gage & $44^{\circ} 16^{\prime} 44^{\prime \prime}$ & $114^{\circ} 44^{\prime} 02^{\prime \prime}$ & NAD83 \\
\hline
\end{tabular}


Suspended-sediment samples and stream discharge measurements were collected at various flows. Discharge measurements, in support of the sediment sampling, were taken using standard USGS methods for collection of streamflow data, computation of discharge, and quality assurance procedures (Buchanan and Somers, 1968, 1969; Carter and Davidian, 1968; Riggs, 1968; Rantz, 1982a, 1982b; Kennedy, 1983, 1984; Simpson, 2001; Helsel and Hirsch, 2002; Turnipseed and Sauer, 2010). Suspended-sediment sample collection and analysis followed techniques and protocols established by the USGS Idaho Water Science Center as documented in the Center's surface-water quality assurance plan (USGS Idaho Water Science Center; 2014) and in Guy (1970), Porterfield (1972), and Edwards and Glysson (1999).

Suspended-sediment samples were collected using width- and depth-integrating techniques to obtain representative samples. Samples were collected using a US-DH-81 sampler when the channel was wadeable and the US-D-95 reel-mounted sampler when sampling from a bridge was necessary. Each site has a bridge to sample from. Johnson (1996), Edwards and Glysson (1999), Davis (2005), Gray and others (2008) provide detailed descriptions of the collection methods and different sampling devices used to sample suspended-sediment.

Suspended-sediment samples were analyzed at the USGS Cascades Volcano Observatory sediment laboratory. Samples were analyzed for total concentration and particle size fraction less than $0.0625 \mathrm{~mm}$. Guy (1969), Matthes and others (1991), and Knott and others (1992a, 1992b) provide a detailed description of the techniques used for the analysis of sediment samples. A quality assurance project plan (QAPP) was not required for this project.

Stream discharge is the driving force for sediment transport and is as important as the sediment samples themselves. Only one of the sampling sites in this study (Gage) was equipped with a real-time continuous streamgage. Therefore, pseudo-hydrographs were developed for the non-gaged Bonanza and Confluence sites. The measured discharge associated with each sample collected at the Bonanza and Confluence sites was correlated with measured discharge from the Gage site. Using the Gage site discharge as a surrogate, regression equations were developed that were then applied to the mean daily stream discharge of the Gage site.

\section{Results}

Twenty-two discharge measurements were obtained at each site from 2012 to 2015 (table 2). Seventeen suspended-sediment samples were collected at the Bonanza and Confluence sites with one additional replicate sample collected at Bonanza on May 18, 2014. Twenty-one suspended-sediment samples were collected at the Gage site. All suspended-sediment samples were analyzed for percentage finer than $0.063 \mathrm{~mm}$ and converted to percentage greater than $0.0625 \mathrm{~mm}$ for these results. More detailed results are discussed in sections, Discharge and Suspended-Sediment. 
Table 2. Stream discharge and suspended-sediment results, Yankee Fork of the Salmon River near Stanley, Idaho.

[Abbreviation: $\mathrm{ft}^{3} / \mathbf{s}$, cubic foot per second; $\mathrm{mg} / \mathrm{L}$, milligram per liter; $\mathrm{mm}$, millimeter; >, greater than]

\begin{tabular}{|c|c|c|c|c|c|c|c|c|c|c|c|c|}
\hline \multirow[b]{3}{*}{ Date } & \multicolumn{12}{|c|}{ Site } \\
\hline & \multicolumn{4}{|c|}{ Bonanza } & \multicolumn{4}{|c|}{ Confluence } & \multicolumn{4}{|c|}{ Gage } \\
\hline & Time & $\begin{array}{c}\text { Discharge } \\
\left(\mathrm{ft}^{3} / \mathbf{s}\right)\end{array}$ & $\begin{array}{l}\text { Suspended- } \\
\text { sediment } \\
\text { concentration } \\
\text { (mg/L) }\end{array}$ & $\begin{array}{c}\text { Percent } \\
\text { suspended } \\
\text { sediment } \\
>0.0625 \mathrm{~mm}\end{array}$ & Time & $\begin{array}{c}\text { Discharge } \\
\left(\mathrm{ft}^{3} / \mathrm{s}\right)\end{array}$ & $\begin{array}{l}\text { Suspended- } \\
\text { sediment } \\
\text { concentration } \\
\text { (mg/L) }\end{array}$ & $\begin{array}{c}\text { Percent } \\
\text { suspended- } \\
\text { sediment } \\
>0.0625 \mathrm{~mm}\end{array}$ & Time & $\begin{array}{c}\text { Discharge } \\
\left(\mathrm{ft}^{3} / \mathrm{s}\right)\end{array}$ & $\begin{array}{c}\text { Suspended- } \\
\text { sediment } \\
\text { concentration } \\
\text { (mg/L) }\end{array}$ & $\begin{array}{c}\text { Percent } \\
\text { suspended } \\
\text { sediment } \\
>0.0625 \mathrm{~mm}\end{array}$ \\
\hline $6 / 5 / 2012$ & $14: 22$ & 707 & & & $13: 22$ & 1270 & & & $11: 32$ & 1686 & 47 & 0.57 \\
\hline $6 / 21 / 2012$ & $13: 28$ & 260 & & & $14: 33$ & 505 & & & $12: 47$ & 648 & 4 & 0.41 \\
\hline $7 / 9 / 2012$ & $12: 47$ & 110 & & & $11: 34$ & 226 & & & $10: 33$ & 252 & 3 & 0.2 \\
\hline $8 / 14 / 2012$ & $8: 25$ & 44.7 & & & $9: 20$ & 93.3 & & & $7: 43$ & 97.9 & 4 & 0.71 \\
\hline $10 / 2 / 2012$ & $8: 19$ & 30.2 & 3 & 0.33 & $9: 19$ & 56.7 & 2 & 0.36 & $10: 54$ & 67 & 3 & 0.42 \\
\hline $11 / 19 / 2012$ & $10: 23$ & 21.2 & 1 & 0.26 & $11: 33$ & 54 & 2 & 0.07 & 13:00 & 63.7 & 2 & 0.16 \\
\hline $4 / 16 / 2013$ & $8: 05$ & 44.6 & 3 & 0.15 & $9: 14$ & 115 & 3 & 0.28 & $10: 31$ & 142 & 5 & 0.12 \\
\hline $4 / 30 / 2013$ & $11: 12$ & 135 & 3 & 0.23 & $11: 48$ & 358 & 11 & 0.25 & $10: 49$ & 412 & 16 & 0.33 \\
\hline $5 / 13 / 2013$ & $11: 46$ & 445 & 29 & 0.41 & $12: 51$ & 914 & 45 & 0.29 & $14: 05$ & 1017 & 51 & 0.3 \\
\hline $5 / 20 / 2013$ & $11: 45$ & 338 & 6 & 0.25 & $12: 51$ & 632 & 9 & 0.23 & 14:04 & 688 & 11 & 0.44 \\
\hline 6/17/2013 & $15: 22$ & 122 & & & $14: 31$ & 220 & & & 13.23 & 245 & & \\
\hline $10 / 29 / 2013$ & $13: 47$ & 30.9 & 2 & 0.31 & 13:04 & 69.4 & 2 & 0.27 & 12:09 & 76.2 & 2 & 0.34 \\
\hline $4 / 8 / 2014$ & $15: 37$ & 55.6 & 16 & 0.2 & $14: 51$ & 111 & 5 & 0.13 & $13: 37$ & 128 & 10 & 0.18 \\
\hline $4 / 22 / 2014$ & $13: 29$ & 237 & 46 & 0.52 & $15: 40$ & 627 & 59 & 0.23 & $17: 17$ & 638 & 61 & 0.16 \\
\hline $5 / 18 / 2014$ & $13: 47$ & 650 & ${ }^{1} 73$ & ${ }^{1} 0.43$ & $15: 41$ & 1320 & 96 & 0.4 & $17: 56$ & 1475 & 111 & 0.45 \\
\hline $5 / 24 / 2014$ & $12: 23$ & 934 & 96 & 0.46 & $13: 48$ & 1500 & 108 & 0.48 & $16: 04$ & 1670 & 131 & 0.52 \\
\hline $5 / 29 / 2014$ & $11: 37$ & 726 & 49 & 0.45 & $13: 19$ & 1420 & 76 & 0.6 & $14: 38$ & 1710 & 86 & 0.57 \\
\hline $6 / 4 / 2014$ & 11:09 & 566 & 22 & 0.55 & $12: 34$ & 1030 & 23 & 0.51 & 14:05 & 1032 & 30 & 0.55 \\
\hline $6 / 19 / 2014$ & $11: 34$ & 221 & 5 & 0.36 & $13: 13$ & 424 & 4 & 0.37 & $14: 55$ & 436 & 7 & 0.41 \\
\hline $5 / 5 / 2015$ & $13: 44$ & 280 & 8 & 0.41 & $12: 43$ & 595 & 24 & 0.32 & $15: 20$ & 629 & 30 & 0.33 \\
\hline $5 / 12 / 2015$ & $10: 30$ & 205 & 3 & 0.29 & $11: 56$ & 463 & 8 & 0.3 & $13: 23$ & 516 & 9 & 0.33 \\
\hline $6 / 16 / 2015$ & $10: 31$ & 141 & 3 & 0.28 & $11: 35$ & 258 & 5 & 0.38 & $12: 48$ & 282 & 5 & 0.24 \\
\hline
\end{tabular}

${ }^{1}$ Replicate associated with this sample had a suspended-sediment concentration of $76 \mathrm{mg} / \mathrm{L}$ with 43 percent of the sample weight $>0.063 \mathrm{~mm}$. 


\section{Discharge}

Discharge from the Bonanza, Confluence, and Gage sites ranged between 21.2 to $934 \mathrm{ft}^{3} / \mathrm{s}, 54$ to $1,500 \mathrm{ft}^{3} / \mathrm{s}$, and 63.7 to $1,710 \mathrm{ft}^{3} / \mathrm{s}$, respectively. The minimum and maximum instantaneous discharge recorded at the Gage site (USGS 13296000) was 16.7 and 2,106 $\mathrm{ft}^{3} / \mathrm{s}$ during this same period. Bonanza and Confluence instantaneous site discharge can be estimated using the Gage site instantaneous discharge as a surrogate. A linear regression between the measured discharge at the ungaged Bonanza and Confluence sites was made with the gaged Gage site. The range of values use in the regression is shown in figure 6. Just upstream of the Confluence site, the ungaged West Fork of the Salmon River enters the Yankee Fork. The discharge from the West Fork makes up most of the difference in discharge between the Bonanza and Confluence sites. Regression equations and statistics are shown in table $3 . \mathrm{R}^{2}$ values for the regressions are 0.96 for Bonanza and 0.98 for the Confluence. Both regressions have high $\mathrm{t}$ stat and low $\mathrm{p}$-values, indicating a strong linear correlation; 95-percent confidence intervals are also provided. 


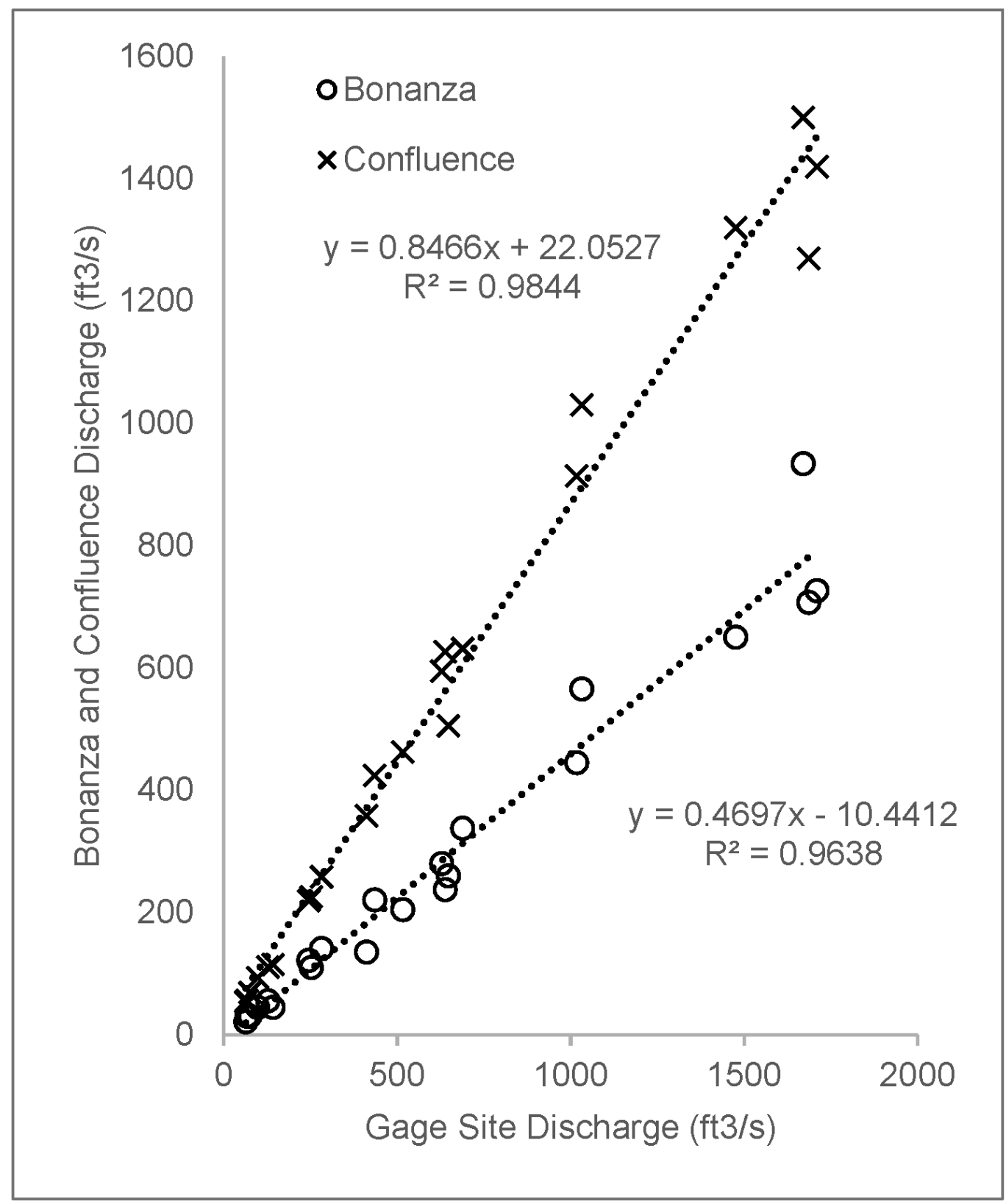

Figure 6. Graph showing stream discharge measurements of the Bonanza and Confluence sites plotted against the Gage site measurements (U.S. Geological Survey streamgage 13296000), Yankee Fork of the Salmon River near Stanley, Idaho. 
Table 3. Pseudo-hydrograph regression statistics for the Bonanza and Confluence sites, Yankee Fork of the Salmon River near Stanley, Idaho.

\begin{tabular}{|c|c|c|c|c|c|c|}
\hline & Coefficients & Standard error & t-stat & p-value & $\begin{array}{c}\text { Lower } 95 \\
\text { percent }\end{array}$ & $\begin{array}{l}\text { Upper 95 } \\
\text { percent }\end{array}$ \\
\hline \multicolumn{7}{|c|}{ Bonanza summary output and regression statistics } \\
\hline Intercept & -10.4412 & 17.0450 & -0.6126 & 0.5471 & -45.9965 & 25.1141 \\
\hline $\mathrm{X}$ variable 1 & 0.4697 & 0.0204 & 23.0674 & 0.0000 & 0.4272 & 0.5122 \\
\hline \multicolumn{7}{|c|}{ Regression statistics } \\
\hline Multiple R & 0.9817 & & & & & \\
\hline $\mathrm{R}$ square & 0.9638 & & & & & \\
\hline Adjusted R square & 0.9620 & & & & & \\
\hline Standard error & 52.3910 & & & & & \\
\hline Observations & 22 & & & & & \\
\hline \multicolumn{7}{|c|}{ Confluence site summary output and regression statistics } \\
\hline Intercept & 22.0527 & 19.9298 & 1.1065 & 0.2816 & -19.5202 & 63.6256 \\
\hline $\mathrm{X}$ Variable 1 & 0.8466 & 0.0238 & 35.5572 & 0.0000 & 0.7969 & 0.8962 \\
\hline \multicolumn{2}{|c|}{ Regression statistics } & & & & & \\
\hline Multiple R & 0.9922 & & & & & \\
\hline $\mathrm{R}$ square & 0.9844 & & & & & \\
\hline Adjusted R square & 0.9836 & & & & & \\
\hline Standard error & 61.2579 & & & & & \\
\hline Observations & 22 & & & & & \\
\hline
\end{tabular}




\section{Suspended Sediment}

Suspended-sediment concentrations show a positive relationship with stream discharge (fig. 7). However, the scatter in the data is primarily caused by a supply limitation. This hysteresis is indicated by the elevated concentration of suspended-sediment in early spring, on the rising limb of the hydrograph. The supply of fine-grained sediment builds up during base flow throughout the year. When a flow greater than base flow and competent enough to transport the fine sediments occurs, it washes the sediment downstream and the supply is mostly exhausted. This pattern of hysteresis is referred to as a supply-limited transport regime. Another indication of this regime is the low concentrations of suspended-sediment on the falling limb of the hydrograph, where flows are sufficient to transport suspended-sediment, but the supply has been depleted during the rising limb of the hydrograph.

The correlation of suspended-sediment compared to discharge between the Confluence and Gage sites is very similar, possibly indicating little to no connectivity with the floodplain and tributaries (table 2). The highly altered and unnatural state of the river is probably conveying most of the fine sediments downstream with little to no deposition or erosion along the margins of the channel.

The percentage of suspended-sediment by weight greater than $0.0625 \mathrm{~mm}$ (percentage of sand) is shown in figure 8 . For all sites, there is a positive relationship between percentage of sand and discharge. The plots indicate that when stream discharge is less than about $400 \mathrm{ft}^{3} / \mathrm{s}$ at the Bonanza site and $1,000 \mathrm{ft}^{3} / \mathrm{s}$ at the Confluence and Gage sites, 10-40 percent of the suspended-sediment consists of sand-sized material (fig. 5). Conversely, when stream discharge is greater than these values, the percentage of sand in transport makes up 40-60 percent of the sample weight. This is a possible sandtransport discharge threshold; where sand transitions from bedload transport to full suspension in the water column. For this report outliers were not addressed, such as the percent sand in Gage site sample on $8 / 14 / 2012$. This analysis will be performed in the final report. 


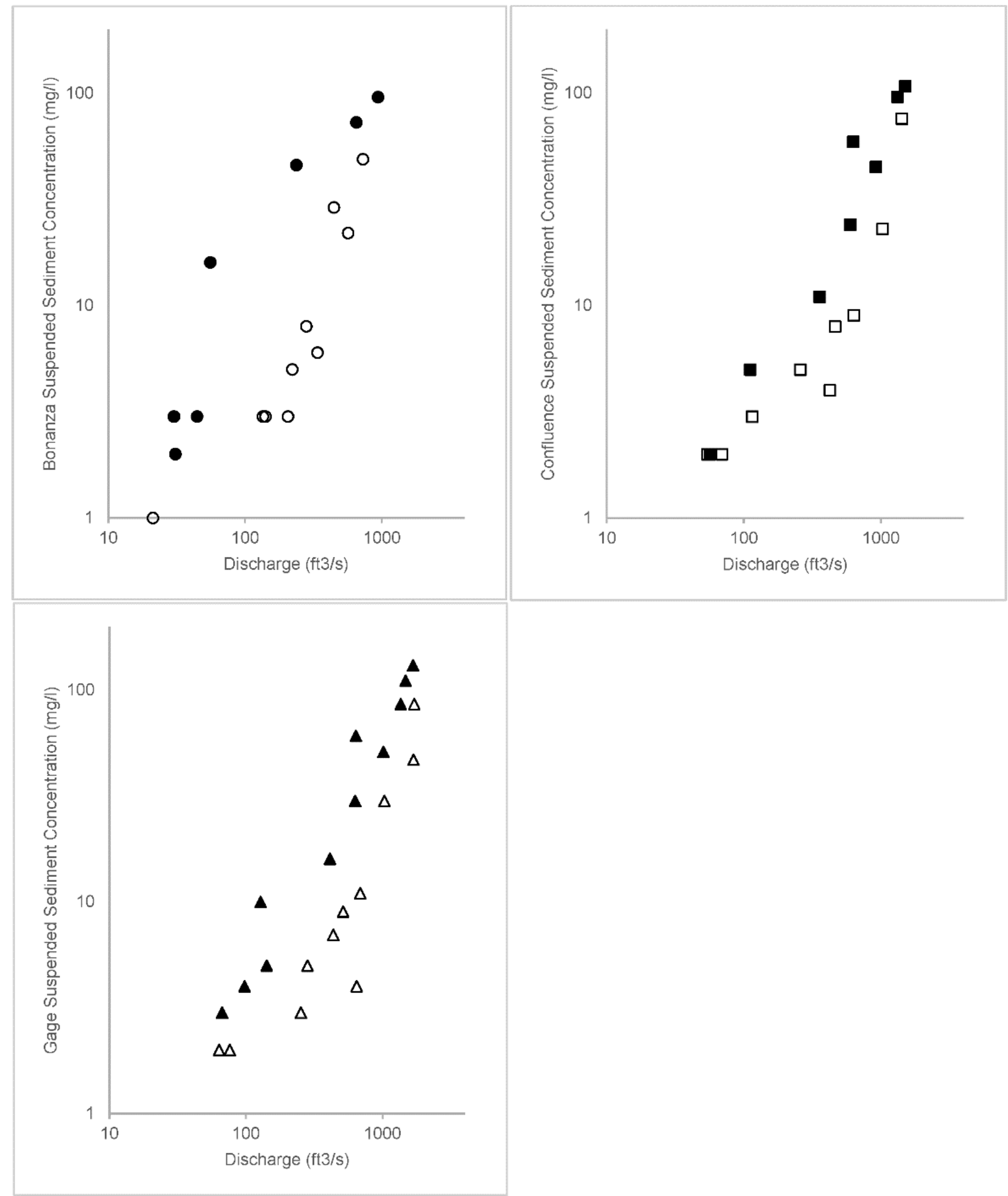

Figure 7. Graphs showing suspended-sediment concentrations plotted against stream discharge measurements for (A) Bonanza, (B) Confluence, and (C) Gage sites, Yankee Fork of the Salmon River near Stanley, Idaho. Black data points indicate samples collected on the rising limb of the hydrograph. 


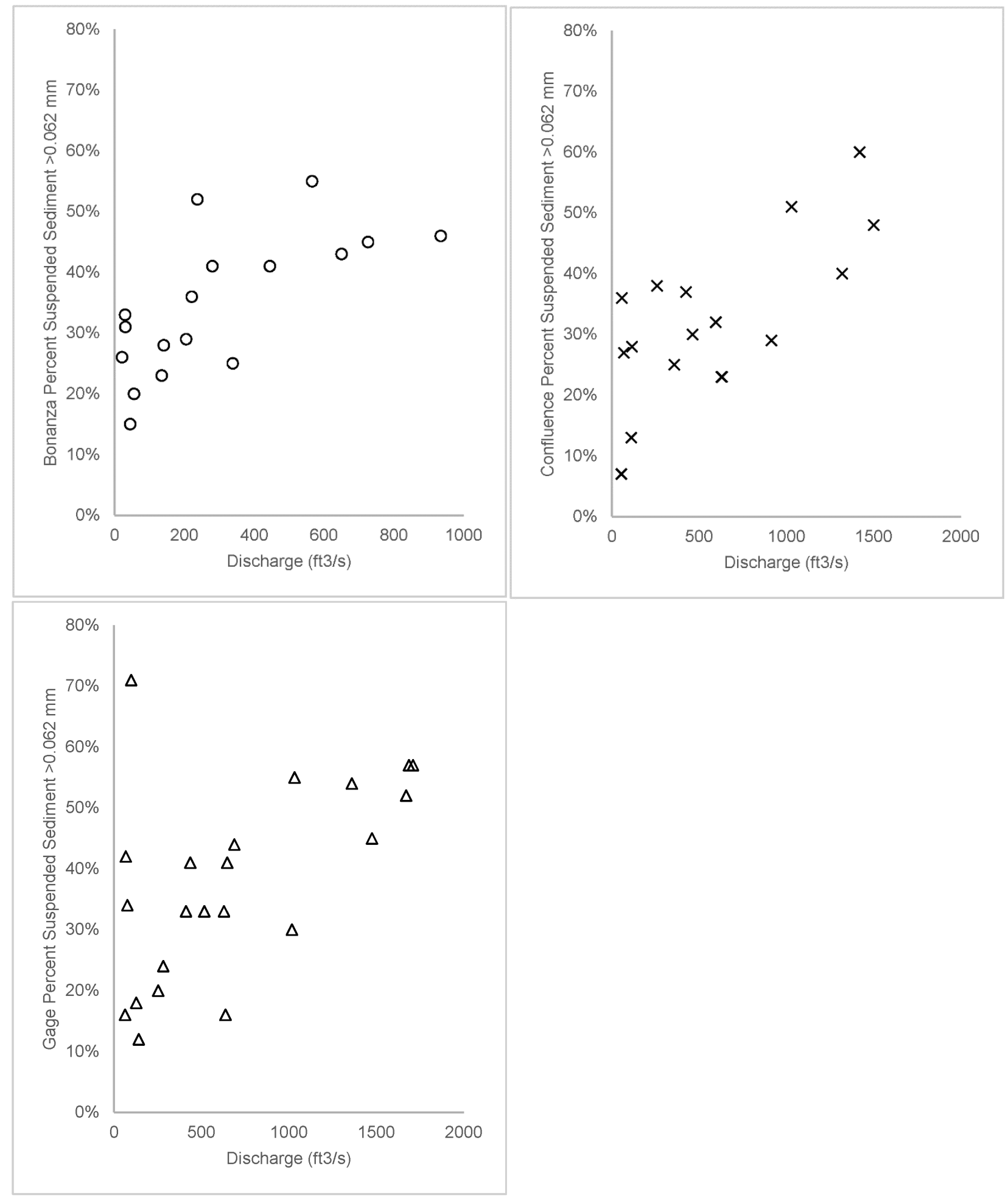

Figure 8. Graphs showing percentage of suspended-sediment sand-size and larger (percentage by weight greater than $0.0625 \mathrm{~mm}$ ) for $(A)$ Bonanza, $(B)$ Confluence, and $(C)$ Gage sites, Yankee Fork of the Salmon River near Stanley, Idaho. 


\section{References Cited}

Buchanan, T.J., and Somers, W.P., 1968, Stage measurements at gaging stations: U.S. Geological Survey Techniques of Water-Resources Investigations, book 3, chap. A7, 28 p.

Buchanan, T.J., and Somers, W.P., 1969. Discharge measurements at gaging stations: U.S. Geological Survey Techniques of Water-Resources Investigations, book 3, chap. A8, 65 p.

Bureau of Reclamation, 2012a, Yankee Fork tributary assessment, Upper Salmon Subbasin, Custer County, Idaho: Boise, Idaho, Department of Interior, Bureau of Reclamation, Pacific Northwest Region, $153 \mathrm{p}$.

Bureau of Reclamation, 2012b, Bonanza area reach assessment, Yankee Fork of the Salmon River, Upper Salmon Subbasin, Custer County, Idaho: Boise, Idaho, Department of Interior, Bureau of Reclamation, Pacific Northwest Region, 92 p.

Bureau of Reclamation, 2012c, Pole Flat area baseline condition assessment, Yankee Fork of the Salmon River, Upper Salmon Subbasin, Custer County, Idaho: Boise, Idaho, Department of Interior, Bureau of Reclamation, Pacific Northwest Region, 80 p.

Bureau of Reclamation, 2013, Yankee Fork fluvial habitat rehabilitation plan, Yankee Fork of the Salmon River, Custer County, Idaho, 2013 Working Version: Boise, Idaho, Department of Interior, Bureau of Reclamation, Pacific Northwest Region, 44 p.

Carter, R.W., and Davidian, J., 1968, General procedure for gaging streams: U.S. Geological Survey Techniques of Water-Resources Investigations, book 3, chap. A6, 13 p.

Colby, B.R., 1956, Relationship of sediment discharge to streamflow: U.S. Geological Survey OpenFile Report, 170 p., https://doi.org/10.3133/ofr5627.

Davis, B.E., 2005, A guide to the proper selection and use of Federally approved sediment and waterquality samplers: U.S. Geological Survey Open-File Report 2005-1087, 20 p.

Edwards, T.K., and Glysson, G.D., 1999, Field methods for measurement of fluvial sediment: U.S. Geological Survey Techniques of Water-Resources Investigations Report, Applications of Hydraulics, book 3, chapter C2, $89 \mathrm{p}$.

Federal Interagency Stream Restoration Working Group, 1998, Stream corridor restoration—Principles, processes, and practices: Prepared by the Federal Interagency Stream Restoration Working Group (FISRWG) (15 Federal agencies of the U.S. Gov’t), GPO Item No. 0120-A; SuDocs No. A 57.6/2:EN3/PT.653, ISBN-0-934213-59-3.

Gray, J.R., Glysson, G.D., and Edwards, T.E., 2008, Suspended sediment samplers and sampling methods, in Sediment transport measurements, chap. 5.3 of Garcia, M., ed., Sedimentation Engineering - Processes, Measurements, Modeling, and Practice: American Society of Civil Engineers Manual 110 p., 320-339.

Guy, H.P., 1969, Laboratory theory and methods for sediment analysis: U.S. Geological Survey Techniques of Water-Resources Investigations, book 5, chap. C1, 58 p.

Guy, H.P., 1970, Fluvial sediment concepts: U.S. Geological Survey Techniques of Water-Resources Investigations, book 3, chap. C1, 55 p.

Helsel D.R., and Hirsch R.M., 2002. Statistical methods in water resources, Techniques of WaterResources Investigations of the United States Geological Survey, Book 4, Hydrologic Analysis and Interpretation, Chapter A3.

Johnson, G.P., 1996, Instruction manual for U.S. Geological Survey sediment observers: U.S. Geological Survey Open-File Report 96-431, 33 p.

Kennedy, E.J., 1983, Computation of continuous records of streamflow: U.S. Geological Survey Techniques of Water-Resources Investigations, book 3, chap. A13, 53 p.

Kennedy, E.J., 1984, Discharge ratings at gaging stations: U.S. Geological Survey Techniques of WaterResources Investigations, book 3, chap. A10, 59 p. 
Knott, K.M., Sholar, C.J., and Matthes, W.J., 1992a, Quality assurance guidelines for the analysis of sediment concentration by U.S. Geological Survey sediment laboratories: U.S. Geological Survey Open-File Report 92-33, 30 p.

Knott, K.M., Glysson, G.D., Malo, B.A., and Schoder, L.J., 1992b, Quality assurance guidelines for the collection and processing of sediment data by U.S. Geological Survey Water Resources Division: U.S. Geological Survey Open-File Report 92-499, 15 p.

Kondolf, G.M., 1995, Five elements for effective evaluation of stream restoration: Restoration Ecology, v. 3, no. 2, p. 133-136. https://doi.org/10.1111/j.1526-100X.1995.tb00086.x.

Kondolf, G.M., and Micheli, E.R., 1995, Evaluating stream restoration projects: Environmental Management, v. 19, no. 1, p. 1-15. https://doi.org/10.1007/BF02471999.

Matthes, W.J., Sholar, C.J., and George, J.R., 1991, Quality-assurance plan for the analysis of fluvial sediment by laboratories of the U. S. Geological Survey: U. S. Geological Survey Open-File Report 91-467, 31 p.

National Oceanic and Atmospheric Administration (NOAA), 2010, Supplemental Consultation on Remand for Operation of the Federal Columbia River Power System, 11 Bureau of Reclamation Projects in the Columbia Basin and ESA Section 10(a)(1)(A) Permit for Juvenile Fish Transportation Program: NOAA's National Marine Fisheries Service, Northwest Region, May 20, 2010, NOAA Fisheries Log No. F/NWR/2010/0209, 40 p.

Porterfield, G., 1972, Computation of fluvial-sediment discharge: U.S. Geological Survey Techniques of Water-Resources Investigations, book 3, chap. C3, 66 p.

Rantz, S.E., 1982a, Measurement and computation of streamflow-Volume 1, measurement of stage and discharge: U.S. Geological Survey Water-Supply Paper 2175, 284 p.

Rantz, S.E., 1982b, Measurement and computation of streamflow-Volume 2, Computation of discharge: U.S. Geological Survey Water-Supply Paper 2175, 631 p.

Rhea, D.T., Farag, A.M., Harper, D.D., McConnell, E., and Brumbaugh, W.G., 2013, Mercury and selenium concentrations in biofilm, macroinvertebrates, and fish collected in the Yankee Fork of the Salmon River, Idaho, USA, and their potential effects on fish health: Archives of Environmental Contamination and Toxicology, v. 64, no. 1, p. 130-139. https://doi.org/10.1007/s00244-012-9816-x

Riggs, H.C., 1968, Some statistical tools in hydrology: U.S. Geological Survey Techniques of WaterResources Investigations, book 4, chap. A1, 30 p.

Simpson, M.R., 2001, Discharge measurements using a broad-band acoustic doppler current profiler: U.S. Geological Survey Open-File Report 01-1, 123 p., accessed April 28, 2017, at https://pubs.usgs.gov/of/2001/ofr0101/text.pdf.

Turnipseed, D.P., and Sauer, V.B., 2010, Discharge measurements at gaging stations: U.S. Geological Survey Techniques and Methods book 3, chap. A8, p. 87, accessed April 28, 2017, at https://pubs.usgs.gov/tm/tm3-a8/.

U.S. Geological Survey, variously dated, National field manual for the collection of water-quality data: U.S. Geological Survey Techniques of Water-Resources Investigations, book 9, chaps. A1-A9. [Also available online at http://pubs.water.usgs.gov/twri9A.]

Wolford, C., 1999, Land of the Yankee Fork: Trailer Life, v. 59, no. 6, 36 p.

Wood, P.J., and Armitage, P.D., 1997, Biological effects of fine sediment in the lotic environment:

Environmental Management, v. 21, no. 2, p. 203-217. https://doi.org/10.1007/s002679900019. 

Publishing support provided by the U.S. Geological Survey Science Publishing Network, Tacoma Publishing Service Center

For more information concerning the research in this report, contact the Director, Idaho Water Science Center

U.S. Geological Survey

230 Collins Road

Boise, Idaho 83702

http://id.water.usgs.gov 
